\title{
The Impact of Organic and Inorganic Manure on the Cultivation of Pumpkin (Cucurbita Maxima)
}

\author{
Uwa Clementina \\ Department of Basic Sciences Institute of Management and Technology Enugu, Enugu State Nigeria
}

\begin{abstract}
A field experiment to assess the effect of organic and inorganic manure on cucurbita was conducted at the demonstration farm at Enugu metropolis Nigeria. The layout was four plots with four replications designed in a complete randomized block design. The treatment were applied at three levels viz: poultry droppings at 5, 10 and 15g, cow dung at 5, 10 and 15g, sheep dung at 15g and NPK at 5, 10 and $15 \mathrm{~g}$ application rates per 195 Square meters respectively. The study revealed that cow dung gave the highest leaf yield, followed by NPK and poultry droppings which gave the next leaf yield. Sheep dung produced the lowest leaf yield during the experimental period. Suggestions were made as to which organic manure is best to be used as an alternative to the inorganic manure (NPK) for the production of cucurbita.
\end{abstract}

Key Words: Organic, Inorganic, Manure, Pumpkin

\section{Introduction}

Cucurbita species is a group of very popular vegetables belonging to many different species. They are one of the common grown leafy vegetables of low land tropics in Asia and Africa. All African species are used for their leaves but on a few occasions they are grown for their seeds ${ }^{[11]}$ and leafy vegetable of high dietary value produced and consumed in most part of Nigeria. Cucurbita species is widely distributed in Malaysia, West Africa, Indonesia and many other tropical regions.

Footnote: Dr. C.U. Uwa is a Principal Lecturer with the Institute of Management and Technology, Enugu, Nigeria, in the Department of Basic Sciences.

It is a genus in the gourd family (cucurbitaceae) first cultivated in the Andes and Mosoamerica and now used in many parts of the world. ${ }^{[13][14]}$ Some species have edible seeds like (the squashes, marrows and pumpkins, and the chilacayote) and some are planted for their fruits. They gourds appear in many color, including blue, orange, yellow, red, and green. It is of various species like cucurbita pepo, C. maxima C. moschata, C. mixta.

The cucurbita maxima species contains varieties that produce pumpkin - like fruit but the skin is usually more yellow than orange and the stems are soft and sponge or corky without riders and without an enlargement next to the fruit. They don't really make good handles for jack-o'-lanterns. Varieties such as Atlantic Giant, Big Max and Show king are often listed as pumpkins but are more properly called pumpkin squash or squash - type pumpkins. Other members of the maxima group are Hubbard squashes, ${ }^{15]}$ Banana squashes, butter cup squashes and turban squashes - in short most autumn and winter squash.

Cucurbita requires little water and grows fastest in semiarid and arid environments $\mathrm{s}^{[7]}$. Warm weather is required during the vegetation period ${ }^{[8]}$. Germination temperature range is between $15^{\circ} \mathrm{C}$ and $37^{\circ} \mathrm{C}$ with an optimum at $25^{0} \mathrm{C}^{[9]}$. Pathogens and insects still affect it, but if left to its own devices in semiarid, it would fare better than the average buttermint from the seed catalog ${ }^{[12]}$.

According to ${ }^{[2]}$, it is an annual plant showing great variation in habit or growth. It is spineless, up to $90 \mathrm{~cm}$ with a strong root system. The stem carries leaves which are green in colour with small flowers in cluster with black-brown shiny seeds. The plant requires a fertile well drained soil. Seeds are sown in rows. The plant does not stay too long on the field therefore; it does not require any intense weeding throughout its life span.

${ }^{[4]}$ stated that the soil fertility of an area or location is very important and optimum productivity may turn to long term economic benefits which will reflect on the yield, meaning that soil fertility management is a vital part of successful crop production. Waste from plants and animals are referred to as organic manure. On the other hand, inorganic fertilizers are usually simple chemical compounds manufactured in factory or obtained by mining which supply essential plant nutrients.

Pumpkin is a warm season vegetable as earlier mentioned which is usually planted after the danger of frost is gone, and the soil has become warm enough for seed germination. Pumpkins actually mature at different times. Pumpkin for Halloween are planted so that they mature as close as possible to the Halloween time, pumpkins for making pre can mature early or late depending on the variety Harvest pumpkin fruits when the 
rain is hard and cannot be poked by finger nail, and the fruit is orange in color. Cuts and bruises should be avoided when harvesting fruits. ${ }^{[15]}$

Application of manure usually increases the number of harvest before sensescene there by suggesting that manure improves growth rate of plants ${ }^{[3]}$. Many studies have shown that application of organic and or inorganic fertilizers increase plant growth mainly because they contain considerable quantities of plant nutrients including micro nutrient which have high benefits for plant growth ${ }^{[5]}$

\section{Objectives}

The objectives of the study are to find out: -

The effect of organic manure on the yield of cucurbita

The effect of inorganic manure on the yield of cucurbita

The interaction between the different levels of organic and inorganic manure.

\section{Materials and Methods}

The field was designed in a randomized complete block design (RCBD) containing four (4) plots with four replicates at 3 levels i.e. 5, 10 and $15 \mathrm{~g}$ of poultry droppings, cow dung, sheep dung and NPK.

Data was obtained during rainy season between July and September 2008 from the demonstration farm in Enugu metropolis which is an urban area, the capital of Enugu state. A low land lying around latitude $6^{\circ} 23^{\prime} \mathrm{N}$ and longitude $7^{0} 30^{\prime} \mathrm{E}$ surrounded by streams and large water holes with an annual rainfall of $1000 \mathrm{~mm}-200 \mathrm{~mm}$ where observations were made on growth and yield of curcubita treated with poultry dung, cow dung, sheep dung and NPK t different levels, respective.

Table 1: Yield of Cucurbita with different treatments

\begin{tabular}{|c|c|c|c|c|c|}
\hline Treatment & Level/rate(g) & Rep i (kg) & Rep ii (kg) & Rep iii(kg) & Rep iv (kg) \\
\hline \multirow[t]{3}{*}{ Poultry Dropping } & 5 & 1.740 & 1.960 & 1.520 & 0.900 \\
\hline & 10 & 1.600 & 1.530 & 1.290 & 0.270 \\
\hline & 15 & 1.400 & 1.960 & 1.420 & 0.080 \\
\hline \multirow{3}{*}{ Cow dung } & 5 & 1.300 & 1.820 & 2.270 & 2.300 \\
\hline & 10 & 0.960 & 2.020 & 1.800 & 2.060 \\
\hline & 15 & 1.600 & 1.580 & 2.400 & 2.400 \\
\hline \multirow{3}{*}{ Sheep dung } & 5 & 1.100 & 0.020 & 0.480 & 1.100 \\
\hline & 10 & 2.220 & 0.460 & 0.460 & 1.020 \\
\hline & 15 & 1.990 & 0.780 & 1.750 & 0.990 \\
\hline \multirow{3}{*}{ NPK } & 5 & 1.190 & 1.800 & 1.210 & 1.200 \\
\hline & 10 & 1.000 & 1.640 & 1.600 & 1.320 \\
\hline & 15 & 0.560 & 1.800 & 1.820 & 1.820 \\
\hline
\end{tabular}

Source: Field Work, 2008.

\section{Hypothesis}

$\mathbf{H}_{\mathbf{O} 1}$ : There is no significant difference between the means of treatments.

$\mathbf{H}_{\mathbf{O} 2}$ : There is no significant difference between the means of three levels of the treatments.

$\mathbf{H}_{\mathbf{0 3}}$ : There is no significant interaction between the treatments and the levels.

\section{Decision Rule}

If the computed $\mathrm{F}$ is greater than the tabulated $\mathrm{F}$, the $\mathrm{H}_{\mathrm{O}}$ is therefore rejected otherwise it is accepted at $5 \%$ level of significance.

Two way analysis of variance was used to analyze the data using Minitab for windows and the result is shown in the table below.

Table: 2

Two-way Analysis of variance

Analysis of variance for REPLICATES

SOURCE

TREATMENT 3

LEVEL 2

INTERACTION 6

ERROR 36

TOTAL 47
DF

1.159

10.758

16.569
SS

1.460

0.136

0.193

MS

INDIVIDUAL 95\% CI 


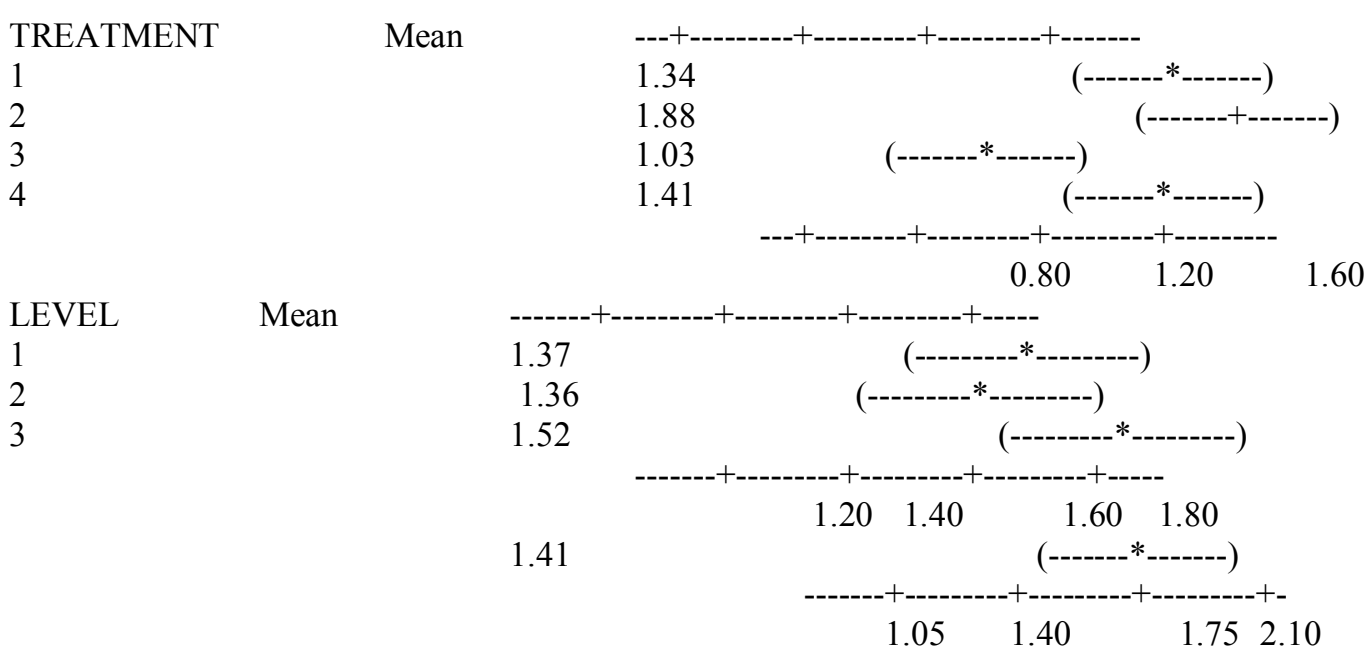

The result of the experiment revealed that $\mathrm{H}_{\mathrm{O} 1}$ was rejected indicating that there is significant difference between the means of treatment while $\mathrm{H}_{\mathrm{O} 2}$ and $\mathrm{H}_{\mathrm{O} 3}$ were accepted meaning there is no significant difference between level of treatments and interaction between treatments and levels.

Cow dung proved to be best with a means yield of 1.88 as compared to NPK Poultry droppings with means yields of 1.41 and 1.34. Cucurbita however showed a very low response to sheep droppings with a means yield of 1.03. This is in line with the findings of ${ }^{[5]}$ that poultry manure has a positive influence on the growth and yield of cucurbita and amaratus leaf.

Similarly ${ }^{[10]}$ reported that vermicompost and NPK significantly influenced the growth and yield of cucurbita.

\section{Conclusion and Recommendation}

In conclusion it is evident that cow dung, NPK and poultry droppings gave higher yield than sheep dung with cow dung giving the highest yield. This means cow dung and poultry droppings re good alternative organic manure for the inorganic manure (NPK) in the production of pumpkin (cucurbita). This is in accordance with findings of ${ }^{[1]}$.

It is therefore recommended that famers should make use of recommended organic and inorganic manure viz cow dung, poultry droppings NPK for better growth and yield of cucurbita especially cow dung and poultry droppings as they are cost effective, less toxic and environment friendly, cheaper and can be readily sourced within the environment which will go a long way in reducing production cost and subsequent yield of cucurbita.

\section{References}

[1]. E.H. Samray, (1979).Journal of agricultural Education Vol. I for Schools and Colleges Published by Ahmadu Bello University Zaira.17-21.

[2]. E.M. Akinsanmi, (1991), Agricultural Science for Senior Secondary Schools ( $3^{\text {rd }}$ edition). Ibadan University Press Limited. 22-23.

[3]. G.W. Cooke, (1982). Fertilizer for maximum yields. Journal of research and development. Auburn University Alabama.vo...1 (22): 396-100.

[4]. I.I., Hignette, E.U., Onweremadu, \& N.N. Oti, (2006). Effective of poultry manure on green cucurbita and amaratus leaf on Degraded Utisol of Owerri South Eastern Nigeria. JAVA 5 (1) 53-6.

[5]. I.I., Ibeawuchi, E.U.,Onweremadu, \& N.N. Oti, (2006). Effects of Poverty Manure on green and Curcubita on degraded utisol of Owerri South Eastern Nigeria. JAVA 5 (1) $53-6$.

[6]. J. Benis, Under exploited Tropical plants with promising economic value, National Research council, 1975, 94-99, ISBN 2978-0$89499-1868$

[7]. J. Berry, J. Berrus, C. Weber, T. Philip, (1978) Cucurbita Root Starches, Isolation and some Properties of starches from cucurbita toetidissima HBK and Agricultural and Food Chemistry 4, 825-826.

[8]. J. Berus, L. Curtis, C. Hiber and J. Berry (1978). The Feral Buffaw Gourd, Cucurbita Foeti. Economic Botany 187-95.

[9]. M. Horak and J. Sweat, 1994.Gerana nation, Emergerke, and Seedling establishment of Buffalo Gourd (Cucurbita foelidissima) Weed Science Society of America 42. 358-363.

[10]. M.N., Alam, M.N., Jahan. M.K., Ali, M.S., Islam, \& S.M. Khandakar, (2007).Effective of vermicompost and NPKS fertilizer on growth and yield components of red cucurbita. Australian Journal of basic and applied sciences 1 (4) 706-16.

[11]. O.C., Ugochukwu, J.O., Otegbade, I. Patrick, E.U., Okeke, \& A. I. Suleiman, (2008). STAN. Agricultural Science for Senior Secondary Schools, Heinnman. Ibadan. 30-31.

[12]. W.M. Raymand, (1973). An Introduction to Soil and Plant Growth $\left(6^{\text {th }}\right.$ edition) Published by International Institute for Tropical Agricultural (IITA) Ibadan. 19-23.

[13]. T.W. Whitaker (1947), “American Origin of Cultivated Cucurbits’ Annals of the Missouri Botanical Garden 34:101-111.

[14]. T.W. Whitaker (1956). "The Origin of the cultivated cucurbita". The American Natusalist 90 (852): 171-176 doi: 10:1086/261923.

[15]. L.D. Osnas (2013) Cucurbita Squash Diversity. Botamistin the King word Press Printed from Urban Next. Illinois. Edu. 